\title{
Immunocytokines: a review of molecules in clinical development for cancer therapy
}

This article was published in the following Dove Press journal:

Clinical Pharmacology:Advances and Applications

19 August 2013

Number of times this article has been viewed

\section{Thomas List \\ Dario Neri}

Department of Chemistry and Applied Biosciences, Swiss Federal Institute of Technology (ETH Zürich), Zurich, Switzerland
Correspondence: Dario Neri

Department of Chemistry and Applied

Biosciences, Swiss Federal Institute

of Technology (ETH Zürich),

Wolfgang-Pauli-Strasse 10, $\mathrm{CH}-8093$

Zurich, Switzerland

Tel +4l 44 633740 I

Email neri@pharma.ethz.ch
Abstract: The concept of therapeutically enhancing the immune system's responsiveness to tumors is long standing. Several cytokines have been investigated in clinical trials for their therapeutic activity in cancer patients. However, substantial side effects and unfavorable pharmacokinetic properties have been a major drawback hampering the administration of therapeutically relevant doses. The use of recombinant antibody-cytokine fusion proteins promises to significantly enhance the therapeutic index of cytokines by targeting them to the site of disease. This review aims to provide a concise and complete overview of the preclinical data and clinical results currently available for all immunocytokines having reached clinical development.

Keywords: antibodies, cytokines, preclinical

\section{Introduction}

The possibility of boosting the immune system's activity against tumors has been the focus of pharmaceutical research for many years. Cytokines are proteins which modulate immune responses and, for this reason, have been considered for therapeutic applications. Ever since the approval in 1995 of the first recombinant cytokine (interferon [IFN]- $\alpha 2$ ) for the treatment of malignant melanoma, interest in cytokines for cancer therapy has increased. ${ }^{1}$ To date, a number of immunostimulatory cytokines, which have shown beneficial effects in preclinical animal models of cancer and in clinical studies, have received marketing authorization (eg, interleukin [IL]-2 [Proleukin ${ }^{\mathrm{TM}}$, Aldesleukin ${ }^{\mathrm{TM}}$; Novartis, Basel, Switzerland], tumor necrosis factor [TNF]- $\alpha$ [Beromun ${ }^{\mathrm{TM}}$; Boehringer Ingelheim, Ingelheim am Rhein, Germany], interferon [IFN]- $\alpha 2$ [Roferon-A ${ }^{\mathrm{TM}}$; Hoffmann-La Roche, Basel, Switzerland, Intron-A ${ }^{\mathrm{TM}}$; Merck \& Co., Whitehouse Station, NJ, USA], and granulocyte-macrophage colony-stimulating factor [GMCSF] [Leukine ${ }^{\mathrm{TM}}$; Genzyme, Cambridge, MA, USA, Leucomax ${ }^{\mathrm{TM}}$; Novartis, Basel, Switzerland]). In addition, immunosuppressive and immunomodulatory cytokines (eg, IL-4 and IL-10) have been considered for treatment of rheumatoid arthritis, psoriasis, and inflammatory bowel disorders.

At present, only a handful of cytokines is in active clinical development. Tumor eradication has been achieved in models of cancer by intratumoral or peritumoral application of cytokines or by implantation of tumor cells expressing cytokines..$^{2-6}$ Yet, these techniques are not readily applicable in the clinical setting, particularly in consideration of the fact that cancer is often a disseminated disease. Systemic administration of cytokines, on the other hand, rarely results in complete cures, and dose escalation is hindered by dose-limiting toxicities (DLTs), which in turn prevent 
the administration of potentially curative regimens. These observations indicate that cytokines are potent modulators of the immune system that can eradicate tumors if high enough concentration is achieved at the site of disease.

With the introduction of monoclonal antibody engineering technology and the identification of tumor-specific and accessible antigens, the targeted delivery of cytokines has become possible. Indeed, the use of antibody-cytokine fusion proteins (immunocytokines) has the potential to improve the therapeutic index of cytokines by concentrating the payload at the site of localized or disseminated disease, thus reducing side effects. A prominent example is represented by the antibody-mediated targeted delivery of IL-12, which has been shown to be at least 20 times more potent than untargeted IL-12 (ie, has achieved a better therapeutic activity at less than $1 / 20$ th of the dose of the unmodified cytokine) in a mouse model of cancer. ${ }^{7}$

While good reviews exist on the topic of immunocytokines, this work focuses on immunocytokines that have reached clinical development (Table 1), aiming to provide an overview of the preclinical data that has led to clinical trials and of emerging clinical results. ${ }^{8-11}$

\section{Formats and biodistribution}

The format of the antibody moiety responsible for the selective targeting of the cytokine payload to the site of disease is of great importance, as pharmacokinetic properties of the fusion protein directly impact on performance. ${ }^{11}$ It would be beyond the scope of this review to discuss all existing formats in detail, but some key considerations need to be presented, to provide a basis for the analysis of clinical-stage products.

Generally, antibody-cytokine fusion proteins can be divided in two categories: (1) large fusion proteins with cytokines fused to the heavy chain of full-scale antibodies (immunoglobulin [Ig]G, >150 kDa) (Figure 1A), and (2) small fusion proteins based on antibody fragments (singlechain variable fragment [scFv], diabodies, $>28 \mathrm{kDa}$ ) (Figure 1B). Different philosophies may lead to the choice of one of these two strategies. IgG-based immunocytokines are preferred if one wishes to achieve long circulatory half-lives in blood. By contrast, smaller immunocytokines may be preferred, if one wishes to keep the blood concentrations of cytokines as low as possible, in order to prevent side-effects. Interestingly, the use of antibody moieties as delivery vehicles is not per se a guarantee that the product will efficiently reach the site of disease in vivo. Immunocytokines may face several potential problems that could prevent in-vivo targeting. Most target antigens are located in perivascular structures, and immunocytokines need to extravasate in order to selectively localize at sites of disease. ${ }^{12}$ Extreme pI (isoelectric point) values, glycosylation, large size, and trapping by a molar excess of accessible cytokine receptors are some of the molecular mechanisms which may limit the selective localization of immunocytokines and, consequently, their therapeutic action. ${ }^{12-17}$ IgGs typically have longer circulatory half-life in the range of days, which is mainly due to the interaction of the Fc (fragment, crystallizable) domain with neonatal Fc receptors. ${ }^{18,19}$ Paradoxically, Fc receptor binding can also have a negative impact by greatly increasing blood clearance time of immunocytokines. ${ }^{20}$ This problem can be solved, however, by introducing mutations in the Fc domain. ${ }^{21}$ The tissue penetration of IgGs has been shown to be slow and heterogenous in solid tumors which are characterized by high interstitial pressure but, because of long circulatory half-life, intact immunoglobulins display a higher tumor uptake compared with antibody fragments. ${ }^{22}$ Small formats, such as monomeric scFvs (28 kDa) may have better tumor penetration compared with $\mathrm{IgG}$, but lack the avidity effects of bivalent antibodies and typically display short retention times at the tumor site. ${ }^{23-25}$ Bivalent recombinant antibodies of intermediate size, such as dimeric $\mathrm{scFv}$ fragments (also called diabodies), scFv-Fc fusions, and minibodies (small immunoprotein [SIP]), may display long residence time at the site of disease and rapid blood clearance. ${ }^{26-28}$ At present, immunocytokines which have progressed to clinical trials are based on antibodies in IgG format or on $\mathrm{ScFv}$ fragments.

\section{Mode of action of immunocytokines}

Different cytokines may activate (or inhibit) different subsets of leukocytes, thus mediating various immune processes. Most pro-inflammatory cytokine payloads (eg, IL-2, TNF, IL-12) mediate the influx of leukocytes at the site of disease. However, cytokines may differ for their activity on regulatory T-cells (IL-2 being a prominent pro-inflammatory cytokine which activates them) and on other cell types. For example, TNF has been reported not only to activate the immune system, but also to be capable of direct tumor cell killing and to promote intravascular blood coagulation of small tumor capillaries. Conversely, immunosuppressive cytokines (eg, IL-10) may exert different effects on the immune system, justifying their possible use as anti-inflammatory agents.

The mechanism of action of immunocytokines is easier to study in mice than in humans, because of the possibility to examine biopsies and to perform therapy experiments 


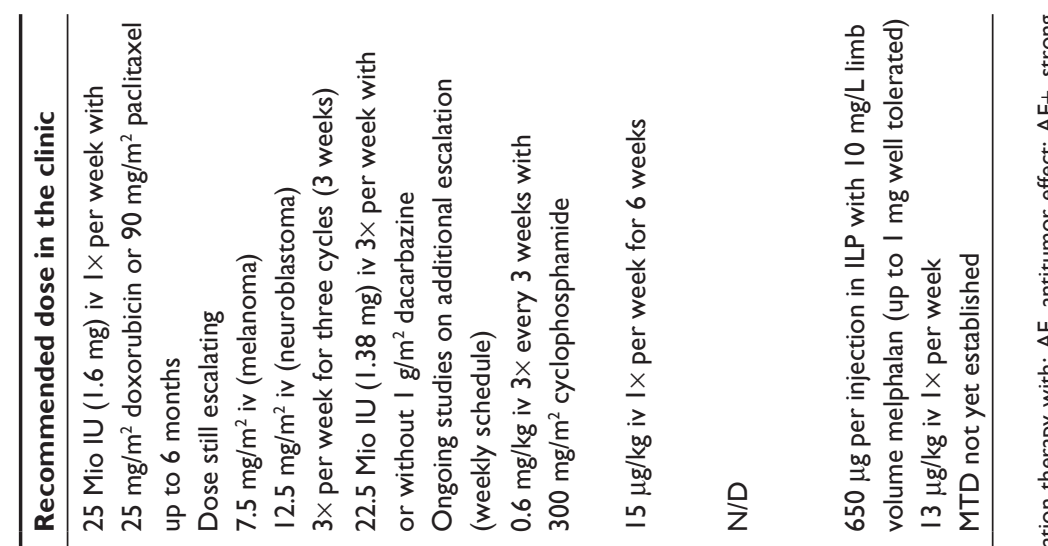

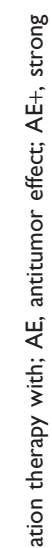

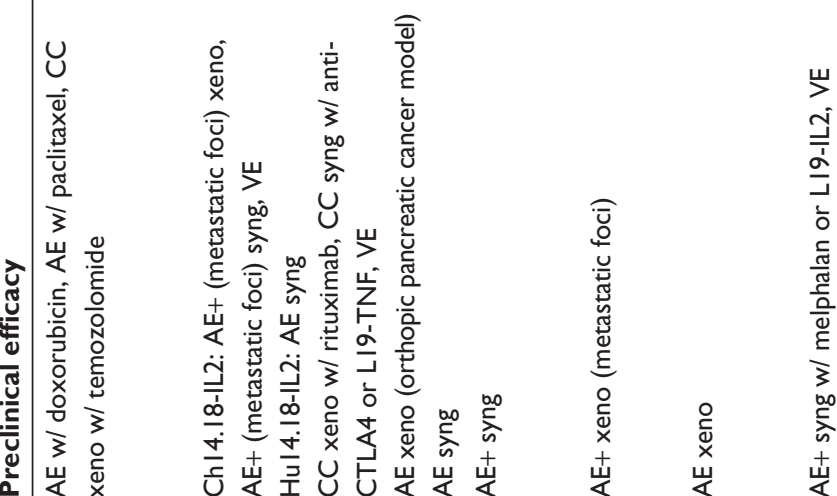

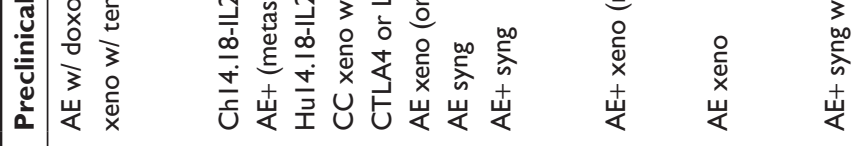

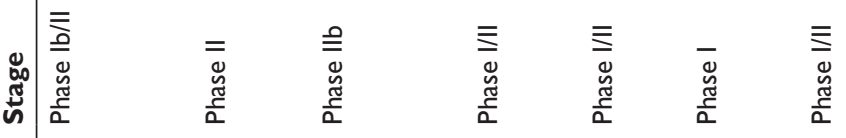

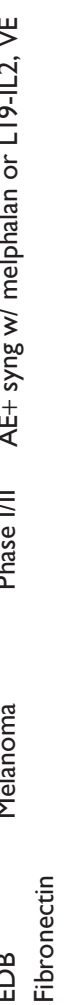

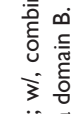

离

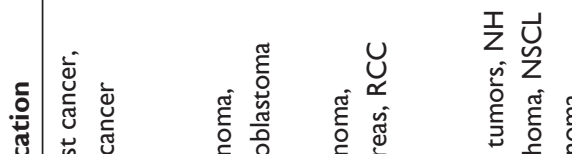
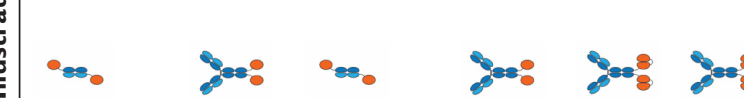

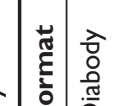

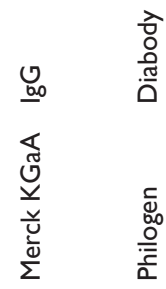<smiles>C1=COCC1</smiles>

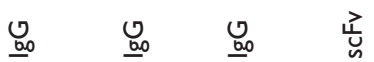

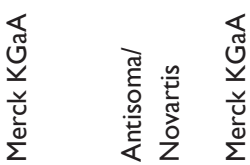


A IgG-cytokine

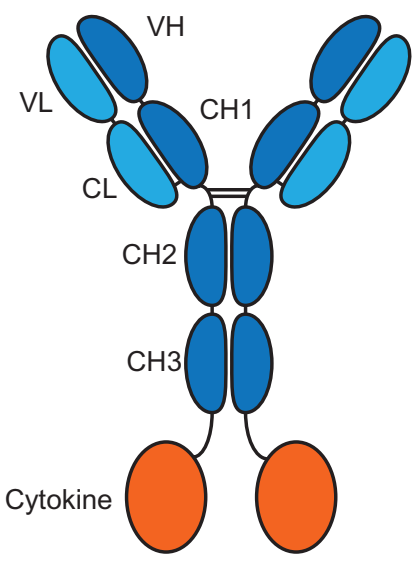

Hu14.18-IL2 NHS-IL2LT

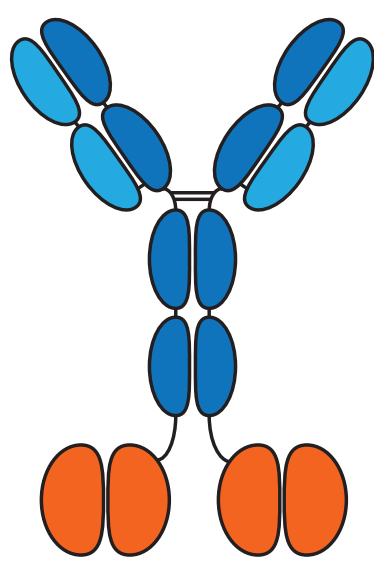

NHS-IL12

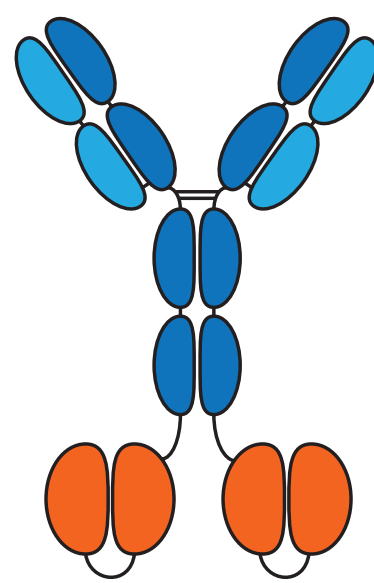

BC1-IL12

B

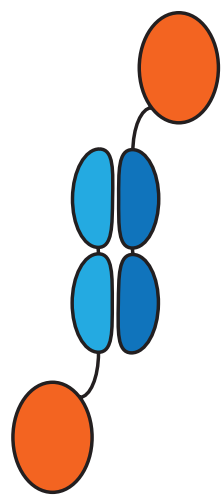

L19-IL2

F16-IL2
scFv-cytokine (trimeric)

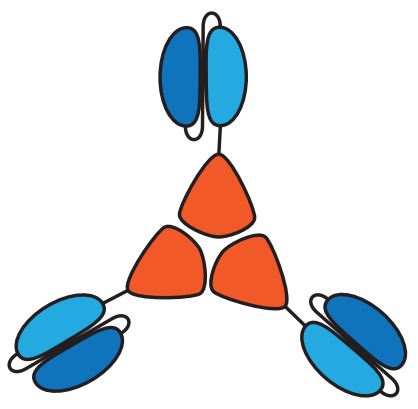

L19-TNF

Figure I Schematic representation of the protein structure of immunocytokines currently in active clinical trials. (A) Immunocytokines based on antibodies in IgG format. (B) Immunocytokines based on antibody fragments (monomeric scFv and dimeric diabody formats).

Abbreviations: IgG, immunoglobulin G; scFv, single-chain variable fragment; VL, variable domain of the immunoglobulin light chain; VH, variable domain of the immunoglobulin heavy chain; $\mathrm{CL}$, constant domain of the immunoglobulin light chain; $\mathrm{CHI}, \mathrm{CH} 2, \mathrm{CH} 3$, constant domains of the immunoglobulin heavy chain; TNF, tumor necrosis factor.

with selective lymphocyte depletion. The contribution of different subsets of immune cells (eg, natural killer [NK] cells and T-cells) is often model-dependent and, at least in mice, there seems to be a strong contribution from the mouse strain used.

When considering IgG-based immunocytokines, one would expect these molecules to be multifunctional, potentially leading to the crosslinking of cytokine receptorpositive cells with those components of the immune system, capable of interacting with the Fc portion of IgG. Intact antibodies can trigger antibody-dependent cellular toxicity
(ADCC) or complement dependent cytotoxicity against the tumor cell it binds to..$^{29,30}$ The relative importance of these two mechanisms of action remains controversial. ${ }^{31}$ Finally, it is useful to draw the analogy between immunocytokines and bispecific antibodies, since both classes of therapeutic proteins are bifunctional agents, which effectively mediate cell crosslinking. An IL-2-based immunocytokine may tether IL-2 receptor-expressing cells to the tumor cell and induce Fas/FasL (Fas/Fas-ligand)-mediated cell death in the target, a mechanism akin to the one reported for cytotoxic bispecific antibodies. $^{32-35}$ 


\section{Current molecular targets of immunocytokines used in the clinic}

Immunocytokines have been developed against various tumor-associated antigens such as carbonic anhydrase 9 (CAIX), epidermal growth factor receptor (EGFR), epithelial cell-adhesion molecule (EpCAM), fibroblast activation protein (FAP), fibronectin splice variants (EDA, EDB), and tenascin splice variants. Yet only immunocytokines specific for a few of these molecular targets have advanced to clinical trials. It is to be noted that the targets that have been explored for targeted therapy by immunocytokines encompass cell-surface proteins as well as components of the tumor microenvironment such as extracellular matrix proteins. In addition, two immunocytokines in clinical trials are based on an antibody which targets nuclear structures that become exposed upon cell lysis in necrotic tumors. Below, we briefly

A

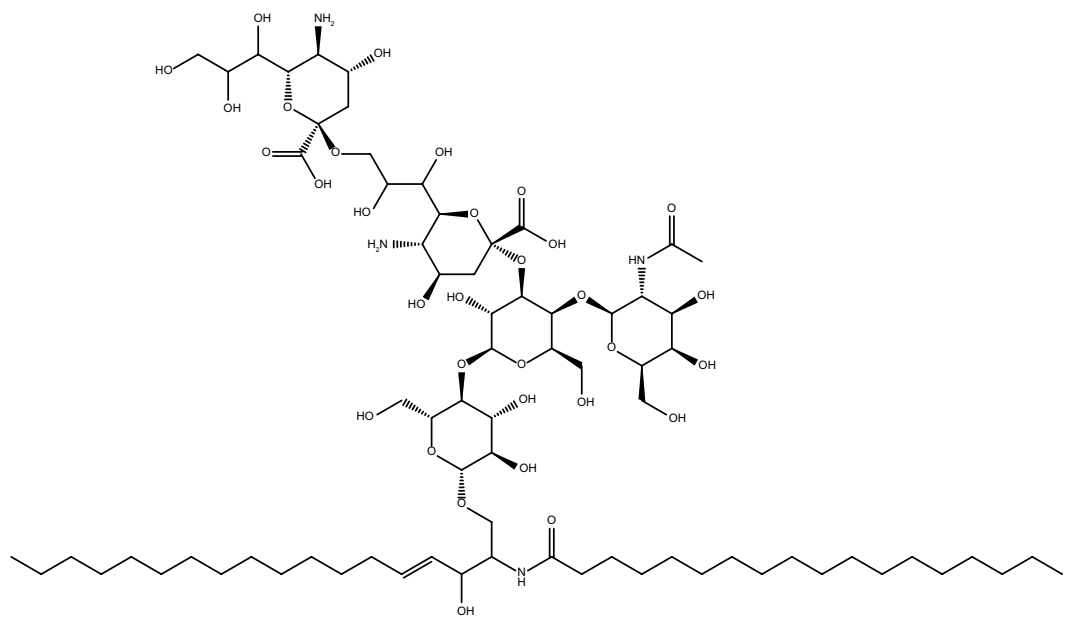

B

$\mathrm{BC} 1$ (cryptic epitope)

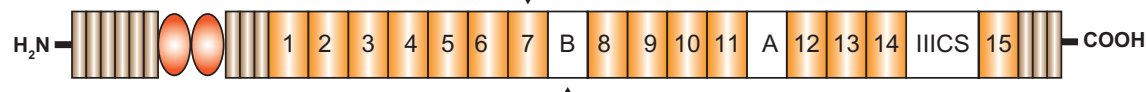

L19

C
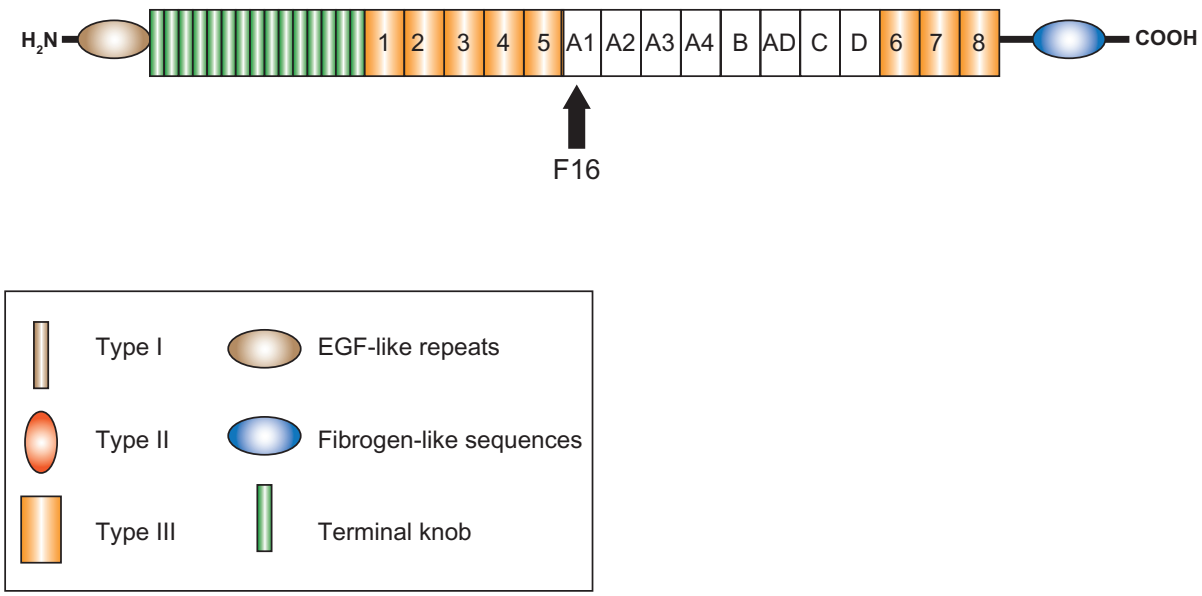

Figure 2 Schematic representation of the structures of tumor antigens targeted by immunocytokines in clinical trials: (A) fibronectin, (B) tenascin-C, and (C) disialoganglioside GD2.

Note: Arrows indicate the epitopes recognized by different antibodies.

Abbreviations: EGF, epidermal growth factor; IIICS, type III connecting segment. 
introduce the tumor antigen targets that immunocytokines in the clinic currently target.

\section{Cell surface (disialoganglioside GD2)}

Neuroblastomas, melanomas, non-B-cell lymphomas, soft tissue sarcomas, small-cell lung cancer, and some osteosarcomas display the disialoganglioside GD2 on their cell surface (Figure 2A). In normal tissues, GD2 expression is limited to neurons, melanocytes, and peripheral pain fibers, making it an attractive tumor-associated antigen. ${ }^{36-41}$

\section{Tumor environment}

In addition to dramatic changes to the tumor cell's genome and proteome as a result of transformation, tumors present another dimension of complexity by creating a "tumor microenvironment." ${ }^{42}$ One of the hallmarks of this microenvironment is tissue remodeling and neo-angiogenesis. As a byproduct of these processes, disease environments can present a number of specific and accessible antigens that can be targeted therapeutically.

\section{Fibronectin extradomain B (EDB)}

Fibronectin is a large glycoprotein ubiquitous in the extracellular matrix of mammalian tissues and plasma. Under tissue remodeling conditions, mechanisms of alternative splicing can lead to the insertion of EDB, an extra 91-amino-acid type III homology domain, into fibronectin (Figure 2B). ${ }^{43,44}$ In healthy individuals, EDB is undetectable, but in many aggressive solid tumors EDB is highly expressed around tumor vasculature. ${ }^{45-48}$ Furthermore EDB is identical in mouse, rat, rabbit, dog, monkey, and man. ${ }^{43}$ The high-affinity antibody L19 recognizes EDB and has been shown to efficiently localize to tumor blood vessels in animal models and cancer patients. ${ }^{26,49-53}$

\section{Tenascin CAI domain}

Tenascins are glycoproteins found in the extracellular matrix of vertebrates. Like fibronectin, isoforms of tenascin can arise through alternative splicing at the site of neo-angiogenesis in tumors. In particular, the $\mathrm{C}$ domain of tenascin is undetectable in normal adult tissue but strongly expressed in a perivascular pattern in brain and lung tumors (Figure 2C). ${ }^{44,54,55}$ The F16 antibody recognizes the extra-domain A1 of tenascin and has shown selective accumulation at the site of tumors and inflammatory disorders in animals and humans. ${ }^{9,56}$

\section{Deoxyribonucleic acid (DNA) and necrotic tumors}

Targeting the necrotic core of tumors, also known as "tumor necrotic therapy" was pioneered by the group of Alan Epstein and relies on the antibody-based recognition of molecular components (eg, histones and DNA) released at sites of cell death, such as necrotic areas in tumors. ${ }^{57-60}$ Anti-histone antibodies have been used for tumor-targeting applications. ${ }^{61}$ The human NHS76 antibody was selected from phage display libraries with the use of cell extracts from Burkitt's lymphoma Raji cells and recognizes nucleic acids exposed by necrotic tumor cells as well as metastases. ${ }^{62,63}$

\section{IL-2-based immunocytokines IL-2 immunology}

IL-2 is a cytokine naturally produced by T-cells that stimulates the proliferation of T- and B-lymphocytes, monocytes, and NK cells in response to antigenic or mitogenic stimulation. Human recombinant IL-2 (Aldesleukin ${ }^{\mathrm{TM}}$ / Proleukin ${ }^{\mathrm{TM}}$ ) produced in bacteria has been approved for the treatment of renal cell carcinoma and melanoma in adults. ${ }^{64,65}$ In the clinic, the agent was shown to promote complete and durable responses in a small portion $(8 \%-10 \%)$ of patients, yet at the expense of substantial toxicities which limited the treatment to physically fit patients and to intensive care units. The most important toxicities were capillary leak syndrome, hypotension, fever, malaise, and nausea. ${ }^{66-68}$

The contribution of NK or T-cells to the antitumor response varies depending on the tumor model used. ${ }^{69,70}$ Despite the observed side effects, IL-2 remains the only cytokine shown to mediate cures in metastatic cancer and consequently immunocytokines based on IL-2 figure amongst the most advanced immunocytokines in the clinic. ${ }^{66,71}$

\section{LI9-IL2 (Darleukin)}

The L19 antibody was isolated from phage display libraries as a binder of the extra-domain B of fibronectin. ${ }^{72}$ It has been extensively used with good tumor accumulation as a vehicle for many payloads including radionuclides, photosensitizers, coagulation factors, and cytokines. ${ }^{10,44,52,73-76}$ The L19-IL2 immunocytokine currently in Phase II clinical trials is a diabody with human IL-2 genetically fused to the C-terminus of each scFv domain, yielding a total of two IL-2 moieties per molecule.

\section{Preclinical observations and results}

L19-IL2 has both excellent tumor targeting properties in vivo, with a tumor to blood ratio of 30:1 at 24-hours postinjection, and a greatly improved therapeutic index over IL-2 cytokine alone or IL-2 fused to an antibody moiety of irrelevant specificity in a syngeneic murine teratocarcinoma model. ${ }^{77,78}$ L19-IL2 showed a markedly stronger antitumor 
effect compared with untargeted IL-2 in an orthopic xenograft model for human pancreatic cancer. Furthermore, ${ }^{79}$ L19-IL2 was able to completely eradicate B-cell lymphoma xenografts in combination with rituximab and localized tumors in syngeneic teratocarcinoma and colon carcinoma models when combined with the blockade of anti-inflammatory receptor CTLA-4 (Cytotoxic T-Lymphocyte antigen 4) or with another immunocytokine L19-TNF. ${ }^{78,80}$ The effector cells responsible for the antitumor activity were identified to be NK cells in depletion experiments. It was further observed that the L19-IL2 combination therapies provided a vaccination effect: cured mice re-challenged with implantation of the same B-cell lymphoma and colon carcinoma cell lines did not develop tumors. ${ }^{77,81}$

\section{Clinical results}

L19-IL2 has been studied in patients with metastatic renal cell carcinoma and is currently being investigated for the treatment of melanoma and of pancreatic cancer. Patients with metastatic renal cell carcinoma are usually treated with doses of recombinant IL-2 of approximately 88-864 Mio IU/week for a total of 6 weeks (an equivalent of $0.66 \mathrm{mg} / \mathrm{kg} /$ week). ${ }^{82}$ For the immunocytokine L19-IL2, dosage can however be reduced, as reported in the first clinical trial in humans, where the recommended dose was established at $67.5 \mathrm{Mio}$ IU/week (an equivalent of $0.05 \mathrm{mg} / \mathrm{kg} /$ week) for 4-6 weeks. ${ }^{83}$ In this Phase I clinical trial, $83 \%$ of patients with metastatic renal cell carcinoma showed disease stabilization after two cycles of intravenous injection with L19-IL2 alone at the recommended dose and a median progression-free survival time of 8 months. ${ }^{83}$ This is in line with the improved therapeutic index of L19-IL2 compared with IL-2 alone reported in preclinical therapy experiments in xenografts models. ${ }^{78}$ A later clinical study assessed the therapeutic potential of L19-IL2 in combination with dacarbazine, by combining three L19-IL2 doses with $1 \mathrm{~g} / \mathrm{m}^{2}$ dacarbazine. In this trial, $28 \%$ of patients ( 8 of 29 ) with metastatic melanoma achieved an objective response, and one patient achieved a complete ongoing response for 21 months. ${ }^{84}$ Median progression-free survival was 14 months. The completed Phase IIa trial continues into Phase IIb (90 patients - ongoing) to assess the antitumor activity in patients of the combination therapy versus dacarbazine alone. L19-IL2 is being studied in combination with gemcitabine for the treatment of patients with pancreas cancer.

L19-IL2 was administered by infusion over 1 hour and was shown to have an in-vivo half-life of about $2-3$ hours. It is not immunogenic, but injections led to transient lymphocytopenia, followed by substantial increase in the number of circulating
T-lymphocytes and NK cells after 10 days. In addition, an overall expansion of the T-reg population was observed between the first day and the end of the treatment cycle..$^{83,84}$

L19-IL2 is well tolerated, with mild and reversible toxicities at the recommended dose of $22.5 \mathrm{Mio} \mathrm{IU} /$ patient/day (equivalent to $1.4 \mathrm{mg} /$ patient/day) in monotherapy or with dacarbazine. The absence of G3 toxicities suggests that the dosage regimen could potentially be further increased. ${ }^{85,86}$

\section{FI6-IL2 (Teleukin)}

F16-IL2 consists of the F16 monoclonal human antibody in diabody format specific for the alternatively spliced A1 domain of tenascin $\mathrm{C}$, genetically fused to two molecules of human IL-2 at the $\mathrm{C}$ terminus of each light chain. It is being developed for the treatment of breast cancer and lung cancer and is currently in clinical Phase $\mathrm{Ib} / \mathrm{II}{ }^{87}$

\section{Preclinical observations and results}

F16-IL2 is an immunocytokine that was shown to significantly improve the antitumor potency of chemotherapeutic agents used in the clinic. Twenty micrograms of F16-IL2 in combination with a high dose of DNA intercalating agent doxorubicin $(4 \mathrm{mg} / \mathrm{kg}$ ) per injection resulted in a significantly improved survival time in mice bearing human breast cancer xenografts and showed a synergistic antitumor effect in combination with the mitotic inhibitor paclitaxel at low $(1 \mathrm{mg} / \mathrm{kg})$ and high $(5 \mathrm{mg} / \mathrm{kg})$ dose with no observed toxicities. ${ }^{88}$ Additionally, BALB/c mice bearing glioblastoma xenografts were cured of their tumors and remained tumor free for 160 days after treatment with five total administrations every third day of $20 \mu \mathrm{g}$ F16-IL2 in combination with $0.525 \mathrm{mg}$ alkylating agent temozolomide per injection. ${ }^{89}$ In biodistribution studies, radiolabelled F16-IL2 showed specific tumor accumulation of $4 \% \mathrm{ID} / \mathrm{g}$ at 24 hours and promoted the infiltration of leukocytes, NK cells, and macrophages into the tumor lesions. ${ }^{88,89}$

\section{Clinical results}

F16-IL2 is currently being evaluated in Phase II clinical trials in patients with various malignancies, but with a focus on lung cancer, breast cancer, and melanoma. Because of the product's synergy with chemotherapeutic drugs, clinical studies have assessed the safety, tolerability, and recommended dose of the immunocytokine in combination with paclitaxel or doxorubicin in humans. The maximal administered doses of doxorubicin $\left(25 \mathrm{mg} / \mathrm{m}^{2}\right)$ and paclitaxel $\left(90 \mathrm{mg} / \mathrm{m}^{2}\right)$ combined with a recommended dose of $1.6 \mathrm{mg}$ (25 Mio IU) F16-IL2 per injection (equivalent to approximately $0.02 \mathrm{mg} / \mathrm{kg}$ ) over 
6 months were well tolerated. Objective responses and longlasting disease stabilization was observed in the paclitaxel combination trial in patients with non-small cell lung carcinoma and melanoma. ${ }^{90}$ In chemotherapeutically pretreated patients with progressive non-small cell lung carcinoma and melanoma, objective responses and long-lasting disease stabilizations were observed, including two partial responses in combination with paclitaxel. ${ }^{91}$ More recently, it has been observed that the administration of higher doses of F16-IL2 is possible, and the product is continuing Phase Ib investigations, in combination with weekly paclitaxel.

Surprisingly, pharmacokinetic analyses in patient blood showed that the half-life was in the range of less than 1 hour, ${ }^{90}$ while the half-life was shown to be of approximately 3 hours in preclinical studies, and was not influenced by the coinjection of doxorubicin. ${ }^{88}$

No DLTs were observed in the trial, and toxicities were mainly of grade 1 (nausea, fever, fatigue), with a few reversible grade 4 toxicities. ${ }^{90}$

\section{Hul 4.I8-IL2 (EMD 273063)}

The ch14.18 antibody is reactive to ganglioside GD2 - a carbohydrate found on the surface of melanomas and neuroblastomas - and contains 75\% human and 25\% murine sequences. ${ }^{38,92}$ Its humanized homologue, hu14.18, contains fully human amino acid sequences in the Fab region, with only the CDR regions being of murine origin. Both the ch14.18-IL2 and hu14.18-IL2 immunocytokine consist of an $\mathrm{IgG}$ antibody genetically fused to two molecules of human IL-2.

\section{Preclinical observations and results}

Fusion of IL-2 to ch14.18 did not impact the antibody's ability to bind GD2-positive neuroblastoma cells, and ch14.18-IL2 was able to enhance ADCC-mediated killing of the tumor cells by activated lymphocytes in vitro. ${ }^{93}$ Ch14.18-IL2 was also able to stimulate proliferation of peripheral blood mononuclear cells isolated from melanoma patients in vitro. ${ }^{94}$ In vivo, radiolabelled ch14.18-IL2 accumulated at the tumor site and in organs bearing experimental metastases in both a metastatic tumor xenografts model and a syngeneic model for metastatic melanoma. ${ }^{70,95}$ Data obtained from mouse serum ELISA (enzyme-linked immunosorbent assay) indicate that, surprisingly, the ch14.18-IL2 fusion protein was cleared twice as rapidly from circulation as the parental ch14.18 antibody alone, with an observed half-life of 4.1 hours for the immunocytokine. Additionally, ch14.18-IL2 was unstable in mouse serum in vitro and appeared to become altered or fragmented after intravenous injection in mice. ${ }^{96}$

Nevertheless, therapy with ch14.18-IL2 was able to markedly reduce the number of metastatic foci found in the liver of mice in a hepatic metastasis model for human neuroblastoma, where the mice were supplied with pre-activated leukocytes. ${ }^{70,93,95}$ In syngeneic settings, treatment of neuroblastoma and melanoma subcutaneous model tumors with ch14.18-IL2 mediated liver metastases eradication and induced a tumor-specific vaccination effect against re-challenge with tumor cells. ${ }^{69,70,97,98}$ The antitumor effect was originally thought to be driven by CD8+ T-cell and NK cell populations as the therapeutic effect of ch14.18-IL2 was lost in severe combined immunodeficiency (SCID) mice. It was later shown that NK cells play a major role as the antitumor response, as the immunocytokine activity could be reduced when NK cells were depleted and enhanced with NK stimulatory agents in vivo, while the tumor infiltrating leukocytes were mainly NK cells. ${ }^{99}$

The humanized hu14.18-IL2 immunocytokine showed modest antitumor activity in animals with a dose-dependent retardation effect followed by recurrence after several weeks. Only the combination of intravenous injections of $22 \mu \mathrm{g} /$ day/mouse ( $70 \mathrm{mg} /$ day in a human) with continuous administration of IL-2 by means of a subcutaneously implanted osmotic pump achieved tumor eradication. ${ }^{99}$

\section{Clinical results}

Hu14.18-IL2 has progressed to Phase II clinical trials for patients with metastatic melanoma and pediatric refractory neuroblastoma. Hu14.18-IL2 is administered as a 4-hour intravenous infusion over three consecutive days at the beginning of each treatment cycle, for a maximum of 3 weeks. ${ }^{39,100-102}$.

In Phase I clinical trials, the maximal tolerated dose (MTD) was established at $7.5 \mathrm{mg} / \mathrm{m}^{2} /$ day for melanoma patients and $12 \mathrm{mg} / \mathrm{m}^{2} /$ day for pediatric neuroblastoma patients. ${ }^{100,102}$ No partial or complete responses were recorded; however, disease stabilization was achieved in $58 \%$ of melanoma patients after the first cycle. Yet only $24 \%$ of patients showed progression-free disease after the second cycle. ${ }^{102}$ In a different study, using lower dosage ( $4 \mathrm{mg} / \mathrm{m}^{2} /$ day), two of nine patients with unresectable melanoma showed disease stabilization. ${ }^{103}$ In neuroblastoma patients, no objective response was observed. ${ }^{100}$ These observations are consistent with the preclinical observation that tumor burden plays an important role in the outcome of therapy: mice starting treatment before day 8 post tumor implantation showed considerably fewer detectable metastases compared with mice who 
started treatment after day $8 .^{99}$ In Phase II, five of 23 pediatric patients with neuroblastoma had complete responses, four of 23 stable disease, and 14 of 23 progressive disease. ${ }^{104}$

Mean half-life in melanoma and neuroblastoma patient serum was 3-4 hours, which is comparable to pharmacokinetic data obtained from mouse studies for the IL-2 component of the fusion protein, where the half-life was 4.1 hours..$^{39,96,102,103}$ In contrast to the aforementioned pharmacokinetic studies in mice where the IL-2 component was cleared while the IgG component remained detectable long after injection into the mouse, the IgG 14.18 component was undetectable in patients after clearance of the serum. Furthermore, hu14.18-IL2 was immunogenic, as 52\% of patients developed anti-idiotypic antibodies. ${ }^{105}$

The toxicities associated with hu14.18-IL2 were mainly grade 2 transient fevers and rigors that resolved upon completion of the 4-hour infusions. Grade 3 hypoxia, hypotension, allergic reactions, and pain requiring morphine were doselimiting toxicities.

\section{NHS-IL2LT (Selectikine, EMD52 I873)}

The NHS-IL2LT immunocytokine consists of the humanized NHS76 antibody in IgG format fused genetically at the C-terminus to a low toxicity mutant of human IL-2 (IL2LT). ${ }^{62}$ The NHS76 antibody binds specifically to nucleic acids and targets the necrotic core of tumors. ${ }^{60}$ Early attempts to reduce toxicity of IL-2 by using an N88R mutant selective for the high affinity IL-2 receptor, showed improved tolerability in low dosing but unfortunately returned to a normal IL-2 associated toxicity profile upon continuous dosing. ${ }^{106}$

The low toxicity mutant IL2LT bears another mutation (D20T) which abrogates its ability to bind to intermediateaffinity but not high-affinity IL-2 receptors found on T-cells and NK cells. Similar results to the N88R mutant were originally observed, but adjustment of the dosing protocol to intermittent rather than continuous injections found IL2LT to be well tolerated in mouse models. ${ }^{107}$

\section{Preclinical observations and results}

NHS-IL2LT acts predominantly on human and murine activated T-cells via the high-affinity IL-2 receptor, but binds only minimally (three orders of magnitude less) to the lowaffinity IL-2 receptor on naïve lymphocytes. ${ }^{107}$

NHS-IL2LT showed a striking antitumor effect in a syngeneic mouse metastatic tumor model by dramatically reducing the metastatic load in the lung and liver when administered intravenously ( $80 \mu \mathrm{g} /$ injection) for 5 consecutive days, starting 4 days after intravenous injection of tumor cells. ${ }^{107}$ This suggests that DNA-targeting immunocytokines may not only be used for the treatment of localized tumors but also for residual disease. Preclinical toxicity profiling of NHS-IL2LT is however not very consistent. In mice, there was a trend for NHS-IL2LT to be less toxic than in the wild-type IL-2 counterpart, as shown by the administration of 20 times higher doses of immunocytokine with less weight loss and fewer animal deaths. ${ }^{107}$ This lower toxicity profile was, however, only maintained when therapy regimens were intermittent as described in cynomolgus monkeys treated in cycles of 21 days, with 3 consecutive days of 1-hour intravenous injections at doses of up to $10 \mathrm{mg} / \mathrm{kg}$, which correlated with lymphocytosis. ${ }^{107}$

\section{Clinical results}

NHS-IL2LT has been investigated as a single agent in a Phase I clinical study, which has established a recommended dose for subsequent Phase II trials and given preliminary evidence on the clinical efficacy of the immunocytokine.

Patients with localized or metastatic refractory solid tumors (including colorectal, ovarian, prostate, renal cell, and skin carcinoma) were injected with 1-hour intravenous infusion at escalating doses on 3 consecutive days every 3 weeks. A subgroup of these patients also received the immunocytokine in combination with the $300 \mathrm{mg} / \mathrm{m}^{2}$ alkylating agent cyclophosphamide and the MTD was found to be $0.6 \mathrm{mg} / \mathrm{kg} .{ }^{108}$ The rationale behind combining immunocytokine treatment with cyclophosphamide is the potentiation of the antitumor activity of the product by depletion of regulatory T-cells. ${ }^{109,110}$

A strong activation of T-cells but only weak activation of NK cells was recorded, which is in line with the expected activity profile of IL2LT. No tumor responses were observed, but prolonged disease stabilization in some patients was achieved. ${ }^{111}$ The absence of an antitumor effect in this study is, however, not entirely conclusive due to the heterogeneity of cancer types and pre-treatments in the patient population.

The increase of peak serum concentrations was dosedependent and linear. The mean serum half-life was approximately 10 hours in patients, which is notably longer than the half-life observed in other IL-2 based immunocytokines. ${ }^{100-103,108}$

The MTD of NHS-IL2LT, with or without cyclophosphamide, was determined at $0.6 \mathrm{mg} / \mathrm{kg}$ in humans, with a grade-3 skin rash being the DLT. ${ }^{108,111}$ In addition, NHSIL2LT had a favorable safety profile associated with typical IL-2-like toxicities such as transient lymphopenia. The immunocytokine induced only mild hypotension and no vascular leak syndrome, two side-effects commonly seen in other IL-2-based immunocytokines. ${ }^{100,101}$ 


\section{IL- I 2 based immunocytokines IL-I 2 immunology}

IL-12 is a $70 \mathrm{kD}$ glycoprotein and heterodimer consisting of the p40 and p35 moieties covalently linked via a disulfide bridge. It is produced by dendritic cells, monocytes, macrophages, neutrophils, and B-cells in response to recognition of pathogens; for example, through toll-like receptors (TLRS). IL-12 mediates both adaptive and innate immunity by stimulating the production of IFN- $\gamma$ in resting and activated peripheral blood lymphocytes, stimulating NK and T-cell effector functions and promoting MHCI (major histocompatibility complex I) processing and presentation. ${ }^{12}$ IL-12 has also established antitumor activity in animal models and in humans. ${ }^{113,114}$ There is a synergistic effect between IL-12 and other cytokines, in particular the combination of IL-12 and IL-2 has been shown in animal models and clinical studies to enhance multiple immunological parameters such as IFN- $\gamma$ production. ${ }^{15,116}$ Early clinical trials with IL-12 have seen responses in metastatic renal cell carcinoma, Kaposi sarcoma (50\%-71\% response rate), T-cell lymphoma (56\%), and non-Hodgkin's lymphoma (21\%). ${ }^{117}$ However, the systemic administration of IL-12 has also been associated with significant toxicities, which have prevented further clinical development. Doses of $1 \mu \mathrm{g} /$ $\mathrm{kg}$ were associated with DLTs such as fever, chills, fatigue, anorexia, nausea, and elevated transaminase levels. The MTD for recombinant human IL12 was established at $0.5 \mu \mathrm{g} / \mathrm{kg} /$ day in humans. ${ }^{113,114}$ By using the L19 antibody fused to IL-12, a therapeutic effect could be achieved at a 20 -fold lower dose, as compared with free recombinant human IL12 in mouse tumor models, resulting in the infiltration of macrophages, NK cells, and elevated IFN- $\gamma$ in the tumors. ${ }^{7}$ Targeted IL-12 was also able to potently inhibit tumor growth in three different immunocompetent syngeneic murine cancer models. ${ }^{118}$

\section{NHS-ILI 2 (hTNT3-IL I 2, MSB-00 I 0360)}

NHS-IL12 is a fusion protein consisting of the necrosisspecific antibody chTNT3 in IgG format genetically fused at the C-terminus to two human IL-12 cytokine molecules, whereby the p35 subunit of IL-12 is genetically fused to the $3^{\prime}$ end of chTNT-3 heavy chain via a glycine/serine linker and the $\mathrm{p} 40$ subunit - encoded separately - forms a covalent heterodimer with $\mathrm{p} 35$.

\section{Preclinical observations and results}

NHS-IL12 is designed to reduce toxicity associated with systemic administration of IL-12 by selectively targeting delivery to necrotic areas of solid tumors. NHS-IL12 was originally expressed in murine myeloma cells and shown to have cytotoxic activity in vitro. When NHS-IL12 was incubated with human tumor cell lines in the presence of pre-activated human peripheral blood lymphocytes, at effector to target cell ratios of 100:1, it showed approximately twofold better lytic activity over the chTNT3 (NHS) antibody alone.

The circulatory half-life of NHS-IL12 in vivo was determined to be 24 hours by injecting mice with ${ }^{125} \mathrm{I}$ radiolabeled fusion protein. The compound reached approximately $3 \% \mathrm{ID} / \mathrm{g}$ after 24 hours. A modest antitumor effect was also shown in a xenograft model with nude mice injected with pre-activated human peripheral blood lymphocytes and subcutaneously implanted with a human prostate cancer cell line. ${ }^{119}$

It is reported that immunohistochemistry studies have demonstrated effective tumor targeting by a version of the immunocytokine containing murine rather than human IL-12 (NHS-muIL12). Furthermore, the antitumor activity of NHS-muIL12 was shown in a study with canines that had developed spontaneous solid tumors. In this study, two of eleven subjects achieved partial responses with a single dose treatment. ${ }^{117}$

\section{Clinical results}

NHS-IL12 is currently in Phase I clinical trials for patients with solid tumors, to determine the maximum tolerated dose and optimal administration schedule. No clinical data in humans has yet been published.

\section{BCI-ILI2 (ASI409)}

$\mathrm{BC} 1-\mathrm{IL} 12$ is a fusion protein consisting of the humanized murine $\mathrm{BC} 1$ antibody in $\mathrm{IgG}$ format, specific for the EDBcontaining splice isoform of fibronectin, genetically fused at the $\mathrm{C}$ terminus of the $\mathrm{Fc}$ domain to the $\mathrm{p} 35$ subunit of IL-12, which in turn forms covalent dimers to the $\mathrm{p} 40$ subunit via a disulfide bridge. The $\mathrm{BC} 1$ antibody binds EDB-containing fibronectin, although its recognized epitope is different from that of L19. BC1 recognizes a cryptic epitope localized on the type III homology repeat 7 and which is masked in fibronectin molecules lacking the EDB sequence. ${ }^{120}$

\section{Preclinical observations and results}

The murine BC-1 antibody has been successfully used to specifically target tumor vasculature in nude mice bearing human tumor xenografts and to image brain tumor mass in glioblastoma patients. ${ }^{121,122}$ Its humanized form (huBC-1) which is used to construct the immunocytokine BC-1-IL12, stains preferentially tumor blood vessels in human renal cell carcinoma samples. 
BC1-IL12 was approximately tenfold less efficient in stimulating proliferation of human peripheral blood mononuclear cells and inducing production of IFN- $\gamma$ from a human cell line in vitro as compared with free IL-12.

In xenogenic murine metastasis and subcutaneous tumor models using SCID mice, huBC1-muIL12 was efficacious in notably reducing metastatic burden. Treatment with 5-7 intravenous injections per day at doses of up to $16 \mu \mathrm{g}$ almost completely eradicated established experimental lung metastases. In three skin tumor models, the antitumor effect was less pronounced, and mice treated with 7 daily intravenous injections at $20 \mu \mathrm{g}$ showed tumor growth retardation by approximately $50 \%$ without curative effect. ${ }^{123}$

A variant of the immunocytokine-containing murine IL-12 (huBC1-muIL12) was used as a surrogate to assess in-vivo plasma half-life and antitumor activity in mice, as human IL-12 is not active in mice. ${ }^{124}$ The pharmacokinetic profile of BC1-IL12 was only assessed by ELISA methods and the human (huBC1-huIL12) and murine (huBC1muIL12) variants performed comparably. A steep alpha phase with a half-life of 0.15 hours on average was followed by a relatively long beta phase where the circulating half-life was determined to be 19 hours.

In addition, the authors report a "surprisingly low toxicity" profile for huBC1-muIL12, referencing the survival of mice despite an intense dosage regimen with up to seven injections per day. However, no quantitative data have been published.

\section{Clinical results}

BC1-IL12 is currently in Phase I/II clinical trials for renal cell carcinoma and malignant melanoma. In cynomolgus monkeys, an MTD of $2.5 \mathrm{mg} / \mathrm{kg}$ was determined over 8 weeks. Additionally, by comparison with the MTD of huIL12 in nonhuman primates and human patients, a tolerable and active dose of $150 \mu \mathrm{g} / \mathrm{kg}$ was estimated and a 10 -fold lower starting dose was used for dose escalation. Renal cell carcinoma and malignant melanoma patients not amenable to surgical or systemic treatment were injected intravenously over 30 minutes at weekly intervals for six cycles at doses of $15 \mu \mathrm{g} / \mathrm{kg}$ or $25 \mu \mathrm{g} / \mathrm{kg}$. In humans, the MTD was established to be $15 \mu \mathrm{g} / \mathrm{kg}-$ corresponding to a 3-5 molar increase in IL-12 compared with the MTD determined for untargeted IL-12. ${ }^{13,114}$ Still, the dose response was weak, with only three of 13 patients with malignant melanoma achieving tumor shrinkage and only one achieving a sustained partial response 17 months later. ${ }^{125}$

The serum half-life of BC1-IL12 was determined to be approximately 21.8 hours. Injection of 15 or $25 \mu \mathrm{g} / \mathrm{kg}$ correlated with a sharp increase in IFN- $\gamma$ and IP10 (interferon gamma induced protein 10) plasma levels, indicative of the activation of cell-mediated immune responses. Additionally ADA (antidrug antibody) responses were seen in all patients. This had, however, no impact on the ability of BC1-IL12 to bind its target EDB, as assayed in vitro. The authors of the trial claim that there was no correlation between ADA titer and clinical response. ${ }^{125}$

Dose-limiting toxicities such as grade 3 and 4 fatigue, anemia, and elevated transaminase levels, indicative of severe liver damage, were observable above $15 \mu \mathrm{g} / \mathrm{kg}$ per week. Some grade 2 toxicities also appeared, such as pyrexia, fatigue, chills, headache, and vomiting. ${ }^{125}$ Overall, toxicities of the BC1-IL12 immunocytokine were lower than those reported for IL-12 alone, providing further evidence for a loss of biological activity of the payload upon antibody fusion.

\section{TNF-based immunocytokines TNF immunology}

TNF- $\alpha$ was originally identified as a serum factor that caused necrosis of certain murine tumors in vivo. ${ }^{126}$ Human TNF is a pleiotropic homotrimeric cytokine that exerts its antitumor activity primarily by activating the endothelium and being toxic to neovasculature in tumors. ${ }^{127,128}$ Commercially available recombinant TNF (Beromun ${ }^{\mathrm{TM}}$ ) is applied clinically to reduce tumor size before surgery or therapeutically if the tumor is nonexcisable in patients with soft tissue sarcoma and melanoma. Its high associated toxicities prevent systemic administration at doses higher than $200 \mu \mathrm{g} / \mathrm{m}^{2}$ (equivalent to approximately $4 \mu \mathrm{g} / \mathrm{kg}$ ). ${ }^{129}$ Thus TNF has only been approved for application in isolated limb perfusion. In this setting, TNF has achieved complete responses (29\%), partial responses (53\%), and limb salvage (82\%) in patients at doses of $4 \mathrm{mg}$ administered by perfusion. ${ }^{130,131}$

\section{LI9-TNF (Fibromun)}

L19-TNF is composed of the L19 antibody in scFv format fused to human TNF. In solution, the immunocytokine assembles into a functional noncovalent homotrimer, forming a trivalent antibody fusion protein. ${ }^{132}$

\section{Preclinical observations and results}

In preclinical evaluations, a variant of L19-TNF-containing murine TNF has been tested (L19-mTNF). L19-mTNF had greater toxic activity against EDB expressing mouse fibroblasts in vitro than TNF alone, and this activity could be competitively inhibited by addition of L19 antibody in excess. This is a strong argument in support of the ability 
of cytokines to exert their biological activity if delivered to the site of disease. Radiolabelled L19-mTNF also localized persistently at the tumor site, with $10 \% \mathrm{ID} / \mathrm{g}$ at 48 hours and a tumor to blood ratio of $700 .^{132}$

In three syngeneic murine tumor models L19-mTNF had potent antitumor activity in combination with melphalan and L19-IL2. Tumor-bearing mice had 95\% necrotic tumors after a single dose $(1 \mathrm{ng} / \mathrm{kg})$ of immunocytokine administered intravenously. In addition, inhibition of tumor growth was fourfold higher in mice treated with L19-mTNF than in mice treated with TNF alone. Injection of L19-mTNF $(0.7 \mu \mathrm{mol} / \mathrm{kg})$ in combination with melphalan $(4 \mathrm{mg} / \mathrm{kg})$ and L19-IL2 (1 mg/kg) had a remarkable - albeit not curative antitumor effect. ${ }^{132}$ The synergistic effect of melphalan with L19-mTNF can be explained by the vasoactive properties of TNF, which may allow higher melphalan accumulation in the tumor tissue. ${ }^{133}$

A single systemic administration of L19-mTNF and melphalan resulted in a high rate of complete tumor eradication in two syngeneic tumor models using fibrosarcoma and colon carcinoma cell lines. In addition, mice cured of their tumors were resistant to tumor re-challenge, effectively rejecting implants of the same cell line and another histologically unrelated syngeneic tumor cell line. ${ }^{134}$

\section{Clinical results}

L19-TNF is currently in Phase I/II clinical trials for systemic administration in sarcoma and for isolated limb perfusion (ILP) in melanoma. The variant of the immunocytokine used in patients contains human TNF.

L19-TNF was administered as ILP (dose up to $650 \mu \mathrm{g}$ corresponding to $250 \mu \mathrm{g}$ TNF) in combination with melphalan (10 mg/L limb volume) in patients with metastatic melanoma, leading to objective responses in the treated limbs but not the rest of the untreated body. Fifty percent of melanoma patients achieved a complete response, which was maintained for 12 months. This is remarkable, as this regimen replaces the standard high-dose regimen of $4000 \mu \mathrm{g}$ untargeted TNF with $650 \mu \mathrm{g}(6.25 \%$ of the TNF dose) targeted L19-TNF and achieved a comparable outcome while being well tolerated. ${ }^{135}$

In the first in-man trial for the systemic application of L19-TNF, patients with various advanced solid tumors received immunocytokine doses up to $13 \mu \mathrm{g} / \mathrm{kg}$ as three intravenous injections in weekly cycles. While the MTD was not reached in this trial and no objective tumor responses were recorded, therapy achieved transient stable disease in 19 of 31 patients. ${ }^{136}$
In systemic application, the serum half-life of L19-TNF was 33.6 minutes, and the maximum peak serum concentration was $73-14 \mu \mathrm{g} / \mathrm{L} .^{136}$

The toxicities associated with L19-TNF when administered as ILP consisted mainly of mild nausea and fever in very few patients only. In systemic intravenous application, toxicities associated with doses of up to $13 \mu \mathrm{g} / \mathrm{kg}$ were mild and transient, consisting mainly of mild chills, nausea, and vomiting but no hematological toxicities. The DLT was grade 3 lumbar pain in one patient. The MTD found in previous trials for administration of untargeted TNF via continuous intravenous injections was considerably lower (between 30 and $40 \mu \mathrm{g} / \mathrm{m}^{2}$, corresponding to approximately $0.7-0.9 \mu \mathrm{g} / \mathrm{kg}$ ) than the well tolerated L19-TNF dose (13 $\mu \mathrm{g} / \mathrm{kg}$, corresponding to $5 \mu \mathrm{g} / \mathrm{kg}$ TNF). ${ }^{137}$

\section{Concluding remarks and outlook}

In this review, we have presented an overview of preclinical and clinical data related to immunocytokines which have been investigated in clinical trials for the treatment of various malignancies. From both preclinical and clinical observations, it is becoming evident that combination therapies involving immunocytokines have, as a rule, outperformed monotherapies as well as conventional chemotherapy, as measured by the rate of complete eradications of disease in the clinical setting. Additionally, combination of immunocytokines with antibody therapeutics was shown to potentiate ADCC by increasing infiltration of leukocytes into the tumor mass. ${ }^{138,139}$ The clinical potential of combining antibody-cytokine fusion proteins with other therapeutic agents is illustrated by the following examples:

1. Pretreatment with IL-2 or TNF-based immunocytokines has been used to increase vascular leakage and increase uptake of therapeutic agents at the tumor site. ${ }^{140,141}$

2. hu14.18-IL2 in combination with fenretinide, a cytotoxic derivative of retinoic acid, has led to a $>5$ years complete response in a neuroblastoma patient. ${ }^{8}$

3. F16-IL2 in combination with doxorubicin or paclitaxel is in Phase Ib clinical trials and has led to long-lasting disease stabilization..$^{90}$

4. L19-IL2 in combination with dacarbazine has led to objective partial responses in eight of 29 patients and to one complete response in metastatic melanoma. This therapy has now moved on to Phase II. ${ }^{84}$

5. Combination studies with F8-IL2 or KS-IL2 (the F8 and KS antibodies are specific for extra-domain A of fibronectin and epithelial cell-adhesion molecule respectively) in combination with paclitaxel show better tumor accumulation and synergistic anticancer effect in murine tumor models. ${ }^{142,143}$ 
6. F16-IL2 in combination with temozolomide achieved complete tumor eradication in a murine glioblastoma model. ${ }^{89}$

7. F8-IL2 potentiates the antitumor performance of the tyrosine kinase inhibitor sunitinib, leading to tumor growth retardation in a xenograft model. ${ }^{144}$

8. L19-IL2 in combination with rituximab has led to complete eradication of B-cell lymphoma xenografts. ${ }^{78}$

9. A bifunctional immunocytokine (KS-IL2/IL12) has synergistic and curative antitumor effect in a mouse tumor model. ${ }^{145}$

10. Combination of L19TNF with L19-IL2 or L19-IL12 achieved tumor eradication in immunocompetent mouse models and induced a vaccination effect. ${ }^{132,134,140,146}$

Despite seemingly antagonistic roles, cytotoxic or cytostatic chemotherapeutic agents, radiotherapy, and immunostimulatory cytokines may be good combination partners. Firstly, the lack of toxic overlap translates into nonadditive MTDs, which in turn allows higher dosing. Secondly, compounds used in chemotherapy can directly or indirectly affect the immune system by altering antigen uptake, MHC expression, antigen crosspresentation, inhibiting regulatory T-cells, increasing vascular permeability or exposing previously inaccessible tumor antigens, and thus contribute to the antitumor effect of the immunocytokine. ${ }^{147}$ Preliminary radiation or immunoablation treatment can have a favorable impact on the outcome on therapy, because immunosuppressive cells are removed and the immune system can redevelop under the influence of endogenous IL-7 and IL-15. ${ }^{8,148}$ An example for this is the observation of increased tumor regressions and survival in mice after radiofrequency ablation and treatment with an IL-2 based immunocytokine. ${ }^{8}$

Some challenges still persist in the immunocytokine field. Preliminary clinical investigations, which are typically performed in late-stage refractory patients, often fail to detect potential antitumor effects, which may decrease the motivation to continue clinical studies in less pretreated patient populations. There is evidence that patients who have not responded to cancer vaccine treatment, may exhibit favorable, good responses to subsequent chemotherapy. A similar effect can be hypothesized for immunocytokines, possibly in relation to an induction and activation of antitumoral T-cells. ${ }^{97,149,150}$

Animal models of cancer may present a bottleneck for discovery. Syngeneic tumor models are genetically less variable than tumors found in humans. The alternative of using xenografts in nude or SCID mice injected with human leukocytes creates an even more artificial environment. Murine cytokines may act differently than their human homologues, and tumor growth rate in mice is faster than in humans.
Despite promising results obtained in preclinical models and encouraging clinical data, much work is still needed to see whether immunocytokines may become standard therapeutic agents. Until now, clinical development activities have been facilitated by the ease of production and low doses per patient. In addition, fully human immunocytokines were not immunogenic in humans. ${ }^{83,136}$ The main challenge for the years to come relates to the possibility to induce objective and durable responses, which cannot be achieved with other therapeutic agents. In preclinical studies, immunocytokines often work best when combined with other drugs (eg, cytotoxic drugs or biological). The sequence dependence of the combination benefit is easy to demonstrate in mouse models of disease but much more cumbersome to investigate in clinical trials. Furthermore, dose-escalation studies may last several years if the initial dose is too low compared with the recommended dose. Improved procedures for the Phase I testing of immunocytokines (alone or in combination) will be crucially important to allow products to be investigated in those Phases (II and III), which provide more information about therapeutic activity and tolerability. Immunocytokines in clinical development have outperformed their untargeted cytokine counterparts in terms of antitumor effect, yet doselimiting toxicities persist.

The history of anticancer therapeutic proteins is often marked by the introduction of agents into clinical practice, which are later improved by the clinical investigation of new combinations, new indications, or new regimens. The field of anticancer immunocytokines is still in its infancy, and for some of the most recent products, the recommended dose is not firmly established. Once a sufficient number of Phase II studies have been performed, with products used alone or in combination, the real clinical potential of this product class will become clearer. The fact that murine tumors, which cannot be cured by conventional chemotherapy, can be eradicated using immunocytokine-based approaches provides a strong motivation for continuing clinical developments in the field.

\section{Disclosure}

Dario Neri is a cofounder and shareholder of Philochem, the company that owns the F8, L19, and F16 antibodies. The authors report no other conflicts of interest in this work.

\section{References}

1. Kirkwood JM, Butterfield LH, Tarhini AA, Zarour H, Kalinski P, Ferrone S Immunotherapy of cancer in 2012. CA Cancer J Clin. 2012;62(5): 309-335.

2. Aoki T, Tashiro K, Miyatake S, et al. Expression of murine interleukin 7 in a murine glioma cell line results in reduced tumorigenicity in vivo. Proc Natl Acad Sci U S A. 1992;89(9):3850-3854. 
3. Barker SE, Grosse SM, Siapati EK, et al. Immunotherapy for neuroblastoma using syngeneic fibroblasts transfected with IL-2 and IL-12. Br J Cancer. 2007;97(2):210-217.

4. Jackaman C, Bundell CS, Kinnear BF, et al. IL-2 intratumoral immunotherapy enhances CD8+ T cells that mediate destruction of tumor cells and tumor-associated vasculature: a novel mechanism for IL-2. J Immunol. 2003;171(10):5051-5063.

5. Koshita Y, Lu Y, Fujii S, et al. Efficacy of TNF-alpha gene-transduced tumor cells in treatment of established in vivo tumor. Int J Cancer. 1995;63(1):130-135.

6. Miller PW, Sharma S, Stolina M, et al. Intratumoral administration of adenoviral interleukin 7 gene-modified dendritic cells augments specific antitumor immunity and achieves tumor eradication. Hum Gene Ther. 2000;11(1):53-65.

7. Halin C, Rondini S, Nilsson F, et al. Enhancement of the antitumor activity of interleukin-12 by targeted delivery to neovasculature. Nat Biotechnol. 2002;20(3):264-269.

8. Gillies SD. Immunocytokines: a novel approach to cancer immune therapy. In: Lustgarten J, Cui Y, Li S, editors. Targeted Cancer Immune Therapy. 2009:241-256.

9. Gutbrodt K, Neri D. Immunocytokines. Antibodies. 2012;1(1):70-87.

10. Pasche N, Neri D. Immunocytokines: a novel class of potent armed antibodies. Drug Discov Today. 2012;17(11-12):583-590.

11. Kontermann RE. Antibody-cytokine fusion proteins. Arch Biochem Biophys. 2012;526(2):194-205.

12. Niesner U, Halin C, Lozzi L, et al. Quantitation of the tumor-targeting properties of antibody fragments conjugated to cell-permeating HIV-1 TAT peptides. Bioconjug Chem. 2002;13(4):729-736.

13. Melkko S, Halin C, Borsi L, Zardi L, Neri D. An antibody-calmodulin fusion protein reveals a functional dependence between macromolecular isoelectric point and tumor targeting performance. Int J Radiat Oncol Biol Phys. 2002;54(5):1485-1490.

14. Halin C, Niesner U, Villani ME, Zardi L, Neri D. Tumor-targeting properties of antibody-vascular endothelial growth factor fusion proteins. Int J Cancer. 2002;102(2):109-116.

15. Hemmerle T, Wulhfard S, Neri D. A critical evaluation of the tumortargeting properties of bispecific antibodies based on quantitative biodistribution data. Protein Eng Des Sel. 2012;25(12):851-854.

16. Gafner V, Trachsel E, Neri D. An engineered antibody-interleukin-12 fusion protein with enhanced tumor vascular targeting properties. Int J Cancer. 2006;119(9):2205-2212.

17. Ebbinghaus C, Ronca R, Kaspar M, et al. Engineered vascular-targeting antibody-interferon-gamma fusion protein for cancer therapy. Int $J$ Cancer. 2005;116(2):304-313.

18. Kuo TT, Aveson VG. Neonatal Fc receptor and IgG-based therapeutics. MAbs. 2011;3(5):422-430.

19. Woof JM, Burton DR. Human antibody-Fc receptor interactions illuminated by crystal structures. Nat Rev Immunol. 2004;4(2): 89-99.

20. Gillies SD, Lan Y, Lo KM, Super M, Wesolowski J. Improving the efficacy of antibody-interleukin 2 fusion proteins by reducing their interaction with Fc receptors. Cancer Res. 1999;59(9): 2159-2166.

21. Gillies SD, Lo KM, Burger C, Lan Y, Dahl T, Wong WK. Improved circulating half-life and efficacy of an antibody-interleukin 2 immunocytokine based on reduced intracellular proteolysis. Clin Cancer Res. 2002;8(1):210-216.

22. Jain RK, Baxter LT. Mechanisms of heterogeneous distribution of monoclonal antibodies and other macromolecules in tumors: significance of elevated interstitial pressure. Cancer Res. 1988; 48(24 Pt 1):7022-7032.

23. Yokota T, Milenic DE, Whitlow M, Schlom J. Rapid tumor penetration of a single-chain Fv and comparison with other immunoglobulin forms. Cancer Res. 1992;52(12):3402-3408.

24. Graff CP, Wittrup KD. Theoretical analysis of antibody targeting of tumor spheroids: importance of dosage for penetration, and affinity for retention. Cancer Res. 2003;63(6):1288-1296.
25. Milenic DE, Yokota T, Filpula DR, et al. Construction, binding properties, metabolism, and tumor targeting of a single-chain Fv derived from the pancarcinoma monoclonal antibody CC49. Cancer Res. 1991; 51(23 Pt 1):6363-6371.

26. Borsi L, Balza E, Bestagno M, et al. Selective targeting of tumoral vasculature: comparison of different formats of an antibody (L19) to the ED-B domain of fibronectin. Int J Cancer. 2002;102(1):75-85.

27. Holliger P, Hudson PJ. Engineered antibody fragments and the rise of single domains. Nat Biotechnol. 2005;23(9):1126-1136.

28. Wu AM, Senter PD. Arming antibodies: prospects and challenges for immunoconjugates. Nat Biotechnol. 2005;23(9):1137-1146.

29. Naramura M, Gillies SD, Mendelsohn J, Reisfeld RA, Mueller BM. Mechanisms of cellular cytotoxicity mediated by a recombinant antibody-IL2 fusion protein against human melanoma cells. Immunol Lett. 1993;39(1):91-99.

30. Alderson KL, Sondel PM. Clinical cancer therapy by NK cells via antibody-dependent cell-mediated cytotoxicity. J Biomed Biotechnol. 2011;2011:379123.

31. Dorai H, Mueller BM, Reisfeld RA, Gillies SD. Aglycosylated chimeric mouse/human IgG1 antibody retains some effector function. Hybridoma. 1991;10(2):211-217.

32. Baeuerle P, Reinhardt C. Bispecific T-cell engaging antibodies for cancer therapy. Cancer Res. 2009;69(12):4941-4944.

33. Lustgarten J, Marks J, Sherman LA. Redirecting effector T cells through their IL-2 receptors. J Immunol. 1999;162(1):359-365.

34. Gubbels JA, Gadbaw B, Buhtoiarov IN, et al. Ab-IL2 fusion proteins mediate NK cell immune synapse formation by polarizing CD25 to the target cell-effector cell interface. Cancer Immunol Immunother. 2011;60(12):1789-1800.

35. Buhtoiarov IN, Neal ZC, Gan J, et al. Differential internalization of hu14.18-IL2 immunocytokine by NK and tumor cell: impact on conjugation, cytotoxicity, and targeting. J Leukoc Biol. 2011;89(4):625-638.

36. Chang HR, Cordon-Cardo C, Houghton AN, Cheung NK, Brennan MF. Expression of disialogangliosides GD2 and GD3 on human soft tissue sarcomas. Cancer. 1992;70(3):633-638.

37. Svennerholm L, Bostrom K, Fredman P, et al. Gangliosides and allied glycosphingolipids in human peripheral nerve and spinal cord. Biochim Biophys Acta. 1994;1214(2):115-123.

38. Mujoo K, Cheresh DA, Yang HM, Reisfeld RA. Disialoganglioside GD2 on human neuroblastoma cells: target antigen for monoclonal antibody-mediated cytolysis and suppression of tumor growth. Cancer Res. 1987;47(4):1098-1104.

39. Yamane BH, Hank JA, Albertini MR, Sondel PM. The development of antibody-IL-2 based immunotherapy with hu14.18-IL2 (EMD273063) in melanoma and neuroblastoma. Expert Opin Investig Drugs. 2009;18(7):991-1000.

40. Cheung NK, Saarinen UM, Neely JE, Landmeier B, Donovan D, Coccia PF. Monoclonal antibodies to a glycolipid antigen on human neuroblastoma cells. Cancer Res. 1985;45(6):2642-2649.

41. Modak S, Gerald W, Cheung NK. Disialoganglioside GD2 and a novel tumor antigen: potential targets for immunotherapy of desmoplastic small round cell tumor. Med Pediatr Oncol. 2002;39(6):547-551.

42. Hanahan D, Weinberg RA. Hallmarks of cancer: the next generation. Cell. 2011;144(5):646-674.

43. Zardi L, Carnemolla B, Siri A, et al. Transformed human cells produce a new fibronectin isoform by preferential alternative splicing of a previously unobserved exon. EMBO J. 1987;6(8):2337-2342.

44. Neri D, Bicknell R. Tumour vascular targeting. Nat Rev Cancer. 2005;5(6):436-446.

45. Carnemolla B, Balza E, Siri A, et al. A tumor-associated fibronectin isoform generated by alternative splicing of messenger RNA precursors. J Cell Biol. 1989;108(3):1139-1148.

46. Kaczmarek J, Castellani P, Nicolo G, Spina B, Allemanni G, Zardi L. Distribution of oncofetal fibronectin isoforms in normal, hyperplastic and neoplastic human breast tissues. Int J Cancer. 1994;59(1): $11-16$. 
47. Castellani P, Viale G, Dorcaratto A, et al. The fibronectin isoform containing the ED-B oncofetal domain: a marker of angiogenesis. Int $J$ Cancer. 1994;59(5):612-618.

48. Castellani P, Borsi L, Carnemolla B, et al. Differentiation between highand low-grade astrocytoma using a human recombinant antibody to the extra domain-B of fibronectin. Am J Pathol. 2002;161(5):1695-1700.

49. List T, Neri D. Biodistribution studies with tumor-targeting bispecific antibodies reveal selective accumulation at the tumor site. MAbs. 2012;4(6):775-783.

50. Viti F, Tarli L, Giovannoni L, Zardi L, Neri D. Increased binding affinity and valence of recombinant antibody fragments lead to improved targeting of tumoral angiogenesis. Cancer Res. 1999;59(2):347-352.

51. Tarli L, Balza E, Viti F, et al. A high-affinity human antibody that targets tumoral blood vessels. Blood. 1999;94(1):192-198.

52. Demartis S, Tarli L, Borsi L, Zardi L, Neri D. Selective targeting of tumour neovasculature by a radiohalogenated human antibody fragment specific for the ED-B domain of fibronectin. Eur J Nucl Med. 2001;28(4):534-539.

53. Santimaria M, Moscatelli G, Viale GL, et al. Immunoscintigraphic detection of the ED-B domain of fibronectin, a marker of angiogenesis, in patients with cancer. Clin Cancer Res. 2003;9(2):571-579.

54. Borsi L, Carnemolla B, Nicolo G, Spina B, Tanara G, Zardi L. Expression of different tenascin isoforms in normal, hyperplastic and neoplastic human breast tissues. Int J Cancer. 1992;52(5):688-692.

55. Carnemolla B, Castellani P, Ponassi M, et al. Identification of a glioblastoma-associated tenascin-C isoform by a high affinity recombinant antibody. Am J Pathol. 1999;154(5):1345-1352.

56. Schwager K, Villa A, Rosli C, Neri D, Rosli-Khabas M, Moser G. A comparative immunofluorescence analysis of three clinical-stage antibodies in head and neck cancer. Head Neck Oncol. 2011;3:25.

57. de Bruin EC, Medema JP. Apoptosis and non-apoptotic deaths in cancer development and treatment response. Cancer Treat Rev. 2008;34(8):737-749

58. Ricci MS, Zong WX. Chemotherapeutic approaches for targeting cell death pathways. Oncologist. 2006;11(4):342-357.

59. Proskuryakov SY, Gabai VL. Mechanisms of tumor cell necrosis. Curr Pharm Des. 2010;16(1):56-68.

60. Epstein AL, Chen FM, Taylor CR. A novel method for the detection of necrotic lesions in human cancers. Cancer Res. 1988;48(20): 5842-5848.

61. Miller GK, Naeve GS, Gaffar SA, Epstein AL. Immunologic and biochemical analysis of TNT-1 and TNT-2 monoclonal antibody binding to histones. Hybridoma. 1993;12(6):689-698.

62. Sharifi J, Khawli LA, Hu P, King S, Epstein AL. Characterization of a phage display-derived human monoclonal antibody (NHS76) counterpart to chimeric TNT-1 directed against necrotic regions of solid tumors. Hybrid Hybridomics. 2001;20(5-6):305-312.

63. Chen S, Yu L, Jiang C, et al. Pivotal study of iodine-131-labeled chimeric tumor necrosis treatment radioimmunotherapy in patients with advanced lung cancer. J Clin Oncol. 2005;23(7):1538-1547.

64. McDermott DF, Regan MM, Atkins MB. Interleukin-2 therapy of metastatic renal cell carcinoma: update of phase III trials. Clin Genitourin Cancer. 2006;5(2):114-119.

65. Philip PA. Interleukin-2 in the treatment of malignant melanoma. Expert Opin Investig Drugs. 1998;7(3):361-371.

66. Rosenberg SA, Yang JC, White DE, Steinberg SM. Durability of complete responses in patients with metastatic cancer treated with high-dose interleukin-2: identification of the antigens mediating response. Ann Surg. 1998;228(3):307-319.

67. Smith FO, Downey SG, Klapper JA, et al. Treatment of metastatic melanoma using interleukin-2 alone or in conjunction with vaccines. Clin Cancer Res. 2008;14(17):5610-5618.

68. McDermott DF, Regan MM, Clark JI, et al. Randomized phase III trial of high-dose interleukin-2 versus subcutaneous interleukin-2 and interferon in patients with metastatic renal cell carcinoma. J Clin Oncol. 2005;23(1):133-141.
69. Lode HN, Xiang R, Dreier T, Varki NM, Gillies SD, Reisfeld RA Natural killer cell-mediated eradication of neuroblastoma metastases to bone marrow by targeted interleukin-2 therapy. Blood. 1998;91(5): 1706-1715.

70. Becker JC, Pancook JD, Gillies SD, Furukawa K, Reisfeld RA. T cellmediated eradication of murine metastatic melanoma induced by targeted interleukin 2 therapy. J Exp Med. 1996;183(5):2361-2366.

71. Atkins MB, Lotze MT, Dutcher JP, et al. High-dose recombinant interleukin 2 therapy for patients with metastatic melanoma: analysis of 270 patients treated between 1985 and 1993. J Clin Oncol. 1999;17(7): 2105-2116.

72. Pini A, Viti F, Santucci A, et al. Design and use of a phage display library. Human antibodies with subnanomolar affinity against a marker of angiogenesis eluted from a two-dimensional gel. J Biol Chem. 1998;273(34):21769-21776.

73. Sauer S, Erba PA, Petrini M, et al. Expression of the oncofetal EDB-containing fibronectin isoform in hematologic tumors enables EDB-targeted 131I-L19SIP radioimmunotherapy in Hodgkin lymphoma patients. Blood. 2009;113(10):2265-2274.

74. Birchler M, Viti F, Zardi L, Spiess B, Neri D. Selective targeting and photocoagulation of ocular angiogenesis mediated by a phage-derived human antibody fragment. Nat Biotechnol. 1999;17(10):984-988.

75. Fabbrini M, Trachsel E, Soldani P, et al. Selective occlusion of tumor blood vessels by targeted delivery of an antibody-photosensitizer conjugate. Int J Cancer. 2006;118(7):1805-1813.

76. Nilsson F, Kosmehl H, Zardi L, Neri D. Targeted delivery of tissue factor to the ED-B domain of fibronectin, a marker of angiogenesis, mediates the infarction of solid tumors in mice. Cancer Res. 2001;61(2): 711-716.

77. Carnemolla B, Borsi L, Balza E, et al. Enhancement of the antitumor properties of interleukin-2 by its targeted delivery to the tumor blood vessel extracellular matrix. Blood. 2002;99(5):1659-1665.

78. Schliemann C, Palumbo A, Zuberbuhler K, et al. Complete eradication of human B-cell lymphoma xenografts using rituximab in combination with the immunocytokine L19-IL2. Blood. 2009;113(10):2275-2283.

79. Wagner K, Schulz P, Scholz A, Wiedenmann B, Menrad A. The targeted immunocytokine L19-IL2 efficiently inhibits the growth of orthotopic pancreatic cancer. Clin Cancer Res. 2008;14(15):4951-4960.

80. Schwager K, Hemmerle T, Aebischer D, Neri D. The immunocytokine L19-IL2 eradicates cancer when used in combination with CTLA-4 blockade or with L19-TNF. J Invest Dermatol. 2013;133(3): 751-758.

81. Menrad A, Menssen HD. ED-B fibronectin as a target for antibody-based cancer treatments. Expert Opin Ther Targets. 2005;9(3):491-500.

82. Yang JC, Sherry RM, Steinberg SM, et al. Randomized study of highdose and low-dose interleukin-2 in patients with metastatic renal cancer. J Clin Oncol. 2003;21(16):3127-3132.

83. Johannsen M, Spitaleri G, Curigliano G, et al. The tumour-targeting human L19-IL2 immunocytokine: preclinical safety studies, phase I clinical trial in patients with solid tumours and expansion into patients with advanced renal cell carcinoma. Eur J Cancer. 2010;46(16): 2926-2935

84. Eigentler TK, Weide B, de Braud F, et al. A dose-escalation and signalgenerating study of the immunocytokine L19-IL2 in combination with dacarbazine for the therapy of patients with metastatic melanoma. Clin Cancer Res. 2011;17(24):7732-7742.

85. Garbe C. Phase I/II study of the tumor-targeting human L19-IL2 monoclonal antibody-cytokine fusion protein in combination with DTIC in metastatic melanoma patients. Vol J Clin Oncol (Meeting Abstracts). 2009;27(Suppl 15):90642009

86. Weide B. Tumor-targeting human L19IL2 monoclonal antibody-cytokine fusion protein in combination with DTIC in chemotherapy-naïve stage IV melanoma patients. J Clin Oncol (Meeting Abstracts). 2010;28(Supp1 $15): 85552010$.

87. Brack SS, Silacci M, Birchler M, Neri D. Tumor-targeting properties of novel antibodies specific to the large isoform of tenascin-C. Clin Cancer Res. 2006;12(10):3200-3208. 
88. Marlind J, Kaspar M, Trachsel E, et al. Antibody-mediated delivery of interleukin-2 to the stroma of breast cancer strongly enhances the potency of chemotherapy. Clin Cancer Res. 2008;14(20): 6515-6524.

89. Pedretti M, Verpelli C, Marlind J, et al. Combination of temozolomide with immunocytokine F16-IL2 for the treatment of glioblastoma. $\mathrm{Br}$ J Cancer. 2010;103(6):827-836.

90. De Braud FG, Catania C, Masini C, et al. Combinations of the immunocytokine F16-IL2 with doxorubicin or with paclitaxel investigated in phase Ib studies in patients with advanced solid tumors. J Clin Oncol (Meeting Abstracts). 2010;28(Suppl 15):e13017.

91. De Braud FG, Catania C, Onofri A, et al. Combination of the immunocytokine F16-IL2 with doxorubicin or paclitaxel in patients with solid tumors: results from two phase Ib trials. J Clin Oncol (Meeting Abstracts). 2011;29(Suppl):abstr 2595.

92. Gillies SD, Reilly EB, Lo KM, Reisfeld RA. Antibody-targeted interleukin 2 stimulates T-cell killing of autologous tumor cells. Proc Natl Acad Sci USA. 1992;89(4):1428-1432.

93. Sabzevari H, Gillies SD, Mueller BM, Pancook JD, Reisfeld RA. A recombinant antibody-interleukin 2 fusion protein suppresses growth of hepatic human neuroblastoma metastases in severe combined immunodeficiency mice. Proc Natl Acad Sci U S A. 1994;91(20): 9626-9630.

94. Hank JA, Surfus JE, Gan J, et al. Activation of human effector cells by a tumor reactive recombinant anti-ganglioside GD2 interleukin-2 fusion protein (ch14.18-IL2). Clin Cancer Res. 1996;2(12):1951-1959.

95. Becker JC, Pancook JD, Gillies SD, Mendelsohn J, Reisfeld RA. Eradication of human hepatic and pulmonary melanoma metastases in SCID mice by antibody-interleukin 2 fusion proteins. Proc Natl Acad Sci US A. 1996;93(7):2702-2707.

96. Kendra K, Gan J, Ricci M, et al. Pharmacokinetics and stability of the ch14.18-interleukin-2 fusion protein in mice. Cancer Immunol Immunother. 1999;48(5):219-229.

97. Becker JC, Varki N, Gillies SD, Furukawa K, Reisfeld RA. Long-lived and transferable tumor immunity in mice after targeted interleukin-2 therapy. J Clin Invest. 1996;98(12):2801-2804.

98. Lode HN, Xiang R, Varki NM, Dolman CS, Gillies SD, Reisfeld RA. Targeted interleukin-2 therapy for spontaneous neuroblastoma metastases to bone marrow. J Natl Cancer Inst. 1997;89(21):1586-1594.

99. Neal ZC, Yang JC, Rakhmilevich AL, et al. Enhanced activity of hu14.18-IL2 immunocytokine against murine NXS2 neuroblastoma when combined with interleukin 2 therapy. Clin Cancer Res. 2004;10(14):4839-4847.

100. Osenga KL, Hank JA, Albertini MR, et al. A phase I clinical trial of the hu14.18-IL2 (EMD 273063) as a treatment for children with refractory or recurrent neuroblastoma and melanoma: a study of the Children's Oncology Group. Clin Cancer Res. 2006;12(6):1750-1759.

101. Ko YJ, Bubley GJ, Weber R, et al. Safety, pharmacokinetics, and biological pharmacodynamics of the immunocytokine EMD 273066 (huKS-IL2): results of a phase I trial in patients with prostate cancer. J Immunother. 2004;27(3):232-239.

102. King DM, Albertini MR, Schalch H, et al. Phase I clinical trial of the immunocytokine EMD 273063 in melanoma patients. J Clin Oncol. 2004;22(22):4463-4473.

103. Ribas A, Kirkwood JM, Atkins MB, et al. Phase I/II open-label study of the biologic effects of the interleukin-2 immunocytokine EMD 273063 (hu14.18-IL2) in patients with metastatic malignant melanoma. J Transl Med. 2009;7:68.

104. Shusterman S, London WB, Gillies SD, et al. Antitumor activity of hu14.18-IL2 in patients with relapsed/refractory neuroblastoma: a Children's Oncology Group (COG) phase II study. J Clin Oncol. 2010;28(33):4969-4975.

105. Hank JA, Gan J, Ryu H, et al. Immunogenicity of the hu14.18-IL2 immunocytokine molecule in adults with melanoma and children with neuroblastoma. Clin Cancer Res. 2009;15(18):5923-5930.
106. Margolin K, Atkins MB, Dutcher JP, et al. Phase I trial of BAY 50-4798, an interleukin-2-specific agonist in advanced melanoma and renal cancer. Clin Cancer Res. 2007;13(11):3312-3319.

107. Gillies SD, Lan Y, Hettmann T, et al. A low-toxicity IL-2-based immunocytokine retains antitumor activity despite its high degree of IL-2 receptor selectivity. Clin Cancer Res. 2011;17(11):3673-3685.

108. Gillessen S, Gnad-Vogt US, Gallerani E, et al. A phase I dose-escalation study of the immunocytokine EMD 521873 (Selectikine) in patients with advanced solid tumours. Eur J Cancer. 2013;49(1):35-44.

109. Lutsiak ME, Semnani RT, De Pascalis R, Kashmiri SV, Schlom J, Sabzevari H. Inhibition of CD4(+)25+T regulatory cell function implicated in enhanced immune response by low-dose cyclophosphamide. Blood. 2005;105(7):2862-2868.

110. Bass KK, Mastrangelo MJ. Immunopotentiation with low-dose cyclophosphamide in the active specific immunotherapy of cancer. Cancer Immunol Immunother. 1998;47(1):1-12.

111. Laurent J, Touvrey C, Gillessen S, et al. T-cell activation by treatment of cancer patients with EMD 521873 (Selectikine), an IL-2/anti-DNA fusion protein. J Transl Med. 2013;11:5.

112. Trinchieri G. Interleukin-12 and the regulation of innate resistance and adaptive immunity. Nat Rev Immunol. 2003;3(2):133-146.

113. Atkins MB, Robertson MJ, Gordon M, et al. Phase I evaluation of intravenous recombinant human interleukin 12 in patients with advanced malignancies. Clin Cancer Res. 1997;3(3):409-417.

114. Gollob JA, Mier JW, Veenstra K, et al. Phase I trial of twice-weekly intravenous interleukin 12 in patients with metastatic renal cell cancer or malignant melanoma: ability to maintain IFN-gamma induction is associated with clinical response. Clin Cancer Res. 2000;6(5): 1678-1692.

115. Li D, Shugert E, Guo M, Bishop JS, O’Malley BW Jr. Combination nonviral interleukin 2 and interleukin 12 gene therapy for head and neck squamous cell carcinoma. Arch Otolaryngol Head Neck Surg. 2001;127(11):1319-1324.

116. Zaki MH, Wysocka M, Everetts SE, et al. Synergistic enhancement of cell-mediated immunity by interleukin-12 plus interleukin-2: basis for therapy of cutaneous T cell lymphoma. J Invest Dermatol. 2002;118(2):366-371.

117. Joseph W, Kim CRH, Marijo Bilusic, et al. First-in-human phase I trial of NHS-IL12 in advanced solid tumors. J Clin Oncol. 2012; 30(Suppl 15):abstr TPS2617.

118. Pasche N, Wulhfard S, Pretto F, Carugati E, Neri D. The antibodybased delivery of interleukin-12 to the tumor neovasculature eradicates murine models of cancer in combination with paclitaxel. Clin Cancer Res. 2012;18(15):4092-4103.

119. Li J, Hu P, Khawli LA, Yun A, Epstein AL. chTNT-3/hu IL-12 fusion protein for the immunotherapy of experimental solid tumors. Hybrid Hybridomics. 2004;23(1):1-10.

120. Carnemolla B, Leprini A, Allemanni G, Saginati M, Zardi L. The inclusion of the type III repeat ED-B in the fibronectin molecule generates conformational modifications that unmask a cryptic sequence. J Biol Chem. 1992;267(34):24689-24692.

121. Mariani G, Lasku A, Balza E, et al. Tumor targeting potential of the monoclonal antibody BC-1 against oncofetal fibronectin in nude mice bearing human tumor implants. Cancer. 1997;80(Suppl 12): 2378-2384.

122. Mariani G, Lasku A, Pau A, et al. A pilot pharmacokinetic and immunoscintigraphic study with the technetium-99m-labeled monoclonal antibody BC-1 directed against oncofetal fibronectin in patients with brain tumors. Cancer. 1997;80(Suppl 12):2484-2489.

123. Lo KM, Lan Y, Lauder S, et al. huBC1-IL12, an immunocytokine which targets EDB-containing oncofetal fibronectin in tumors and tumor vasculature, shows potent anti-tumor activity in human tumor models. Cancer Immunol Immunother. 2007;56(4):447-457.

124. Zou JJ, Schoenhaut DS, Carvajal DM, et al. Structure-function analysis of the p35 subunit of mouse interleukin 12. J Biol Chem. 1995;270(11): 5864-5871. 
125. Rudman SM, Jameson MB, McKeage MJ, et al. A phase 1 study of AS1409, a novel antibody-cytokine fusion protein, in patients with malignant melanoma or renal cell carcinoma. Clin Cancer Res. 2011;17(7):1998-2005.

126. Palladino MA, Bahjat FR, Theodorakis EA, Moldawer LL. AntiTNF-alpha therapies: the next generation. Nat Rev Drug Discov. 2003;2(9):736-746.

127. Watanabe N, Niitsu Y, Umeno H, et al. Toxic effect of tumor necrosis factor on tumor vasculature in mice. Cancer Res. 1988;48(8): 2179-2183.

128. Fajardo LF, Kwan HH, Kowalski J, Prionas SD, Allison AC. Dual role of tumor necrosis factor-alpha in angiogenesis. Am J Pathol. 1992;140(3):539-544.

129. Gamm H, Lindemann A, Mertelsmann R, Herrmann F. Phase I trial of recombinant human tumour necrosis factor alpha in patients with advanced malignancy. Eur J Cancer. 1991;27(7):856-863.

130. Eggermont AM, Schraffordt Koops H, Klausner JM, et al. Isolated limb perfusion with tumor necrosis factor and melphalan for limb salvage in 186 patients with locally advanced soft tissue extremity sarcomas. The cumulative multicenter European experience. Ann Surg. 1996;224(6):756-764; discussion 764-765.

131. Bonvalot S, Laplanche A, Lejeune F, et al. Limb salvage with isolated perfusion for soft tissue sarcoma: could less TNF-alpha be better? Ann Oncol. 2005;16(7):1061-1068.

132. Borsi L, Balza E, Carnemolla B, et al. Selective targeted delivery of TNFalpha to tumor blood vessels. Blood. 2003;102(13):4384-4392.

133. de Wilt JH, ten Hagen TL, de Boeck G, van Tiel ST, de Bruijn EA, Eggermont AM. Tumour necrosis factor alpha increases melphalan concentration in tumour tissue after isolated limb perfusion. $\mathrm{Br} J$ Cancer. 2000;82(5):1000-1003.

134. Balza E, Mortara L, Sassi F, et al. Targeted delivery of tumor necrosis factor-alpha to tumor vessels induces a therapeutic $\mathrm{T}$ cell-mediated immune response that protects the host against syngeneic tumors of different histologic origin. Clin Cancer Res. 2006;12(8):2575-2582.

135. Papadia F, Basso V, Patuzzo R, et al. Isolated limb perfusion with the tumor-targeting human monoclonal antibody-cytokine fusion protein L19-TNF plus melphalan and mild hyperthermia in patients with locally advanced extremity melanoma. J Surg Oncol. 2013;107(2):173-179.

136. Spitaleri G, Berardi R, Pierantoni C, et al. Phase I/II study of the tumour-targeting human monoclonal antibody-cytokine fusion protein L19-TNF in patients with advanced solid tumours. J Cancer Res Clin Oncol. 2013;139(3):447-455.

137. Schwartz JE, Scuderi P, Wiggins C, Rudolph A, Hersh EM. A phase I trial of recombinant tumor necrosis factor (rTNF) administered by continuous intravenous infusion in patients with disseminated malignancy. Biotherapy. 1989;1(3):207-214.

138. Liu Z, Smyth FE, Renner C, Lee FT, Oosterwijk E, Scott AM. Anti-renal cell carcinoma chimeric antibody G250: cytokine enhancement of in vitro antibody-dependent cellular cytotoxicity. Cancer Immunol Immunother. 2002;51(3):171-177.
139. Friedberg JW, Neuberg D, Gribben JG, et al. Combination immunotherapy with rituximab and interleukin 2 in patients with relapsed or refractory follicular non-Hodgkin's lymphoma. $\mathrm{Br} J$ Haematol. 2002;117(4):828-834.

140. Halin C, Gafner V, Villani ME, et al. Synergistic therapeutic effects of a tumor targeting antibody fragment, fused to interleukin 12 and to tumor necrosis factor alpha. Cancer Res. 2003;63(12):3202-3210.

141. Hornick JL, Khawli LA, Hu P, Sharifi J, Khanna C, Epstein AL. Pretreatment with a monoclonal antibody/interleukin-2 fusion protein directed against DNA enhances the delivery of therapeutic molecules to solid tumors. Clin Cancer Res. 1999;5(1):51-60.

142. Moschetta M, Pretto F, Berndt A, et al. Paclitaxel enhances therapeutic efficacy of the F8-IL2 immunocytokine to EDA-fibronectin-positive metastatic human melanoma xenografts. Cancer Res. 2012;72(7): 1814-1824.

143. Holden SA, Lan Y, Pardo AM, Wesolowski JS, Gillies SD. Augmentation of antitumor activity of an antibody-interleukin 2 immunocytokine with chemotherapeutic agents. Clin Cancer Res. 2001;7(9):2862-2869.

144. Frey K, Schliemann C, Schwager K, Giavazzi R, Johannsen M, Neri D. The immunocytokine F8-IL2 improves the therapeutic performance of sunitinib in a mouse model of renal cell carcinoma. $J$ Urology. 2010;184(6):2540-2548.

145. Gillies SD, Lan Y, Brunkhorst B, Wong WK, LiY, Lo KM. Bi-functional cytokine fusion proteins for gene therapy and antibody-targeted treatment of cancer. Cancer Immunol Immunother. 2002;51(8):449-460

146. Balza E, Carnemolla B, Mortara L, et al. Therapy-induced antitumor vaccination in neuroblastomas by the combined targeting of IL-2 and TNFalpha. Int J Cancer. 2010;127(1):101-110.

147. Zitvogel L, Apetoh L, Ghiringhelli F, Kroemer G. Immunological aspects of cancer chemotherapy. Nat Rev Immunol. 2008;8(1): 59-73.

148. Wrzesinski C, Restifo NP. Less is more: lymphodepletion followed by hematopoietic stem cell transplant augments adoptive T-cellbased anti-tumor immunotherapy. Curr Opin Immunol. 2005;17(2): 195-201.

149. Gribben JG, Ryan DP, Boyajian R, et al. Unexpected association between induction of immunity to the universal tumor antigen CYP1B1 and response to next therapy. Clin Cancer Res. 2005;11(12) 4430-4436.

150. Antonia SJ, Mirza N, Fricke I, et al. Combination of p53 cancer vaccine with chemotherapy in patients with extensive stage small cell lung cancer. Clin Cancer Res. 2006;12(3 Pt 1):878-887.
Clinical Pharmacology: Advances and Applications

\section{Publish your work in this journal}

Clinical Pharmacology: Advances and Applications is an international, peer-reviewed, open access journal publishing original research, reports, reviews and commentaries on all areas of drug experience in humans. The manuscript management system is completely online and includes a very quick and fair peer-review system, which is all easy to use.

\section{Dovepress}

Visit http://www.dovepress.com/testimonials.php to read real quotes from published authors. 